\title{
A Teacher's Will nor His Strategies, Guides Itself to Motivate the Learners' Desires
}

\author{
Edilmar P. Masuhay, Msmathed ${ }^{1}$ \\ ${ }^{1}$ Surigao State College of Technology Mainit Campus, Magpayang, Mainit, Surigao del Norte, Philippines \\ Correspondence: Edilmar P. Masuhay, Msmathed, Surigao State College of Technology Mainit Campus, Magpayang, \\ Mainit, Surigao del Norte, Philippines.
}

Received: September 3, 2018

Accepted: October 3, $2018 \quad$ Available online: October 12, 2018

doi:10.11114/ijsss.v6i11.3686

URL: https://doi.org/10.11114/ijsss.v6i11.3686

\begin{abstract}
The teacher himself, not his motivational skills and his teaching strategies that guide his students to be more confident and aspired. As if this study relates to the life of teachers, the researcher with this recommends that every teacher should bear in mind that "the desired teacher is a leader that shall always keep the best means for his students." The study interprets that Filipinos mathematicians' in this generation are majority woman, and responsive young professionals, endowed with virtues of being a loner, enthusiast, and well mannered. Common sense indulged that students with positive virtues were practically easy to transform but delimit students with behavioral problems.
\end{abstract}

Keywords: teacher's classroom behavior, teacher's instructional techniques, teacher's motivational skills, students responses to a teacher, CARAGA State University

\section{Introduction}

\subsection{Introduction to the Problem}

The country's leading educational reforms and its development probably focus much in upgrading the country's educational system with an inclination to the professional growth of the faculty, and technological advances that provide first-hand opportunities for both the teacher and the learners (pupils and students). However, issues unto the learners' conceptions are quietly behind, and the readiness of the teachers is mainly based on their skills and qualifications (Acosta \& Acosta, 2016). While, strategic teaching in the classroom on "how to teach" was preferably to produce competent graduates with excellent performance that renown their field of expertise, which merely adds-on merit for the university's prestige. (Guzman, 2003). Whereas, this case surely predestine the students to go beyond the institutional platform and overshadowed all concern therein.

Educators tended to be more competent in their field of expertise and wishing to enhance their students' qualities based on the curriculum designed with their expectations and somehow prejudged the learners that lead to frustrations and depressions and impacted the philosophies of the students that made him gloomy especially the mediocre (Urhahne, 2015).

And the worst is it infected the other subjects taught in the curriculum because his time management has been ruined at all. But then, a Microteaching is with this introduced as other means of teaching at any age level, as an effective learning technique for effective teaching. Whereby, it describes that learning is a change of behavior, which is brought about by activity, training, or experiencing at any age. This method also increased teacher's self-confidence in an atmosphere of friendliness and patience (Ramesh, 2013). Then, also considering this shared quotation of Bale Gates that "Technology is just a tool. Concerning getting the kids working together and motivating them, the teacher is most important" that Teacher is the crucial figure in the school. The Teacher expected to initiates techniques and strategies that create a meaningful and favorable atmosphere in which the educational process and set the goals for the school in allotting resources needed to arrive at the desirable teaching-learning situation (Oginni \& Owolabi, 2012).

Occasionally, the researcher has amazed onto his professor's strategies in teaching Mathematical investigation and modeling at Caraga State University (CSU), Ampayon, Butuan City, Philippines. His discoveries tell that his teacher has its desirable virtues and appropriate methodology that may convene to transform his students' resemblance to the desired outcomes. He is one of a kind, a teacher and a good leader, that always keeps a good idea for his students to do 
something better. The scenario has inspired the author and decided to draw a certain perspective by prima-facie evidence. So, as far as teacher-educator-researcher is a concern, and in the pursuit of national development and progress. Hereafter, the study on the Learners' perspective on their teacher's instructional techniques in Mathematical investigation and modeling of graduate studies at CSU has been explored to justify the means.

\subsection{Objectives of the Study}

The study aimed to measure the perspective views of CSU graduate student. First, what are the profile of graduate students in Mathematics investigation and modeling in preference to socio-demographic records: sex, age, marital status, baccalaureate degree, the status of appointment, number of siblings, and home address? Second, what are the learners perspective towards their teacher's instructional techniques in terms to the proportion of students who are comfortable with their teacher's methodology, the portion of students who think that teacher is using the appropriate instructional techniques for the subject? Third, what are the feelings of the learners' about their teacher's methodology in terms of the proportion of students with best learning moment when they are alone, when they are with their classmates, or when they are with their teacher, the proportion of students who prefer to have their teacher's feedback to their performance right away, the next session, or anytime thru email? Fourth, what makes the instructional techniques appropriate to the subject taught in terms of the proportion of students has home access to internet, the proportion of students who think computer can help them in learning, the proportion of students who prefer face-to-face interaction with their teacher, the proportion of students who are comfortable communicating in writing, the proportion of students who enjoy reading? Fifth, what makes the teacher's instructional techniques are effective regarding the proportion of students who are self-motivated and self-disciplined, the proportion of students with confidence to learn the subject? And Six, investigate the following hypotheses: $\mathrm{H}_{1}$ : Students personal and socio-demographic has no significance to their attitudes and habits in the Classroom; $\mathrm{H}_{2}$ : Teacher instructional techniques have significance to motivate, conveyed the learners and learned the topics; $\mathrm{H}_{3}$ : Teacher virtues has significance in transforming their students; $\mathrm{H}_{4}$ : Technology has significance in communication; and $\mathrm{H}_{5}$ : There is no significant relationship between the teacher's instructional techniques across the learners' personal and the related socio-demographic records of the students.

\subsection{Theoretical Framework}

Entirely the theoretical framework of the theory of Flick (2002) shall be benchmark, wherein the flow shall be wholly followed: formulation of the overall question, formulation of specific research question, formulation of sensitizing concepts, selection of research groups with which to study the issue, selection of appropriate designs and methods, evaluation and reformation of the specific questions, collection of data, analyzing of data, generalization and assessment of the analyses and formulation of the findings (Prado, N.L., Penaso, A.M., Cimene, F.T., Aves, L.S., \& Simbulas, S.G., 2011).The research process followed the diagrammatic presentation of the steps taken when doing research (Prieto, et al., 2017). The hypotheses are formulated before the study is conducted because they provide direction for data collection, analysis, and interpretation. Hence, the hypothesis flow from the problem statement, literature review, and theoretical framework.

\section{Materials and Methods}

The study has utilized the following instruments: First, the Judge's Items Rating Form for determining the Content Validity, (Prado et al., 2011). Methods of Research, page 134, Source: Martuza, Hambleton, and Bausell, as cited by Gregory (1996), applied to pre-determine the validity of the questionnaire with the principles of Comery (1973) rated orthogonal factor loadings as follows: 0.73 and above is excellent; $0.63-0.70$ is very good; $0.55-0.62$ is good; 0.45 0.54 is Fair; and $0.32-0.44$ is Poor. Second, the Semantic Differential Scale and Likert Scale, Prado (1995) used as a tool during the conduct of face-to-face questioning and interview, answered questions/hypotheses relevant to learner's perspective on their teacher's instructional techniques and the attitudes of the learners in the Classroom, in the scale specified from 1 to 5. Wherein 1, is equated to Strongly Disagree (SD); 2, is Disagree (D); 3, is Neutral (N); 4, is Agree (A); and 5, is Strongly Agree (SA). Third, Descriptive statistics, were utilized in computing the mean values of the learners' perspective on their teacher's instructional techniques that includes: frequency and percentages and standard deviation, with criterion for mean values as follows: Very Low 1.0 - 1.80; Low 1.81 - 2.60; Average 2.61 - 3.40; High 3.41 - 4.20; and Very High 4.21 - 5.0 interpreted the data gathered. Fourth, Statistical Package for Social Sciences (SPSS) processor was done through described the data for presentation purposes.

Technically, the study undergo the following activities: the validity of questionnaire tried by ten (10) selected experts of which evidently reflected that the instrument is valid with an average rating score of 0.85 , accumulated from all of the areas, with an average factor loading count of Part I, 0.8, Part II, 0.68, Part III, 0.93, and Part IV is 1.0; determining the number of contributors thru purposive sampling considering 20 respondents; the conduct of face-to-face questioning and interview every Saturday classes schedules only during their free time and leisure; tallied and tabulated group of data in order to account the number of distribution; answered questions and hypotheses by frequency counts and 
percentages by using a frequency table and calculated the frequency counts and percentages of those enumerated variables thru SPSS for presentation (Prado, et al.,2011).

\section{Results and Discussion}

The area of the study is in Caraga State University, and the provinces of Agusan del Norte, Agusan del Sure, Surigao del Norte and Surigao del Sur, northeast of Mindanao, south of the Philippines. Based on data the campus, has 232-hectare area, thirty-two (32) hectares of which is allocated for academic buildings and support facilities including a Gymnasium, while the remaining two-hundred (200) hectares of land is for production, research and extension projects of the University (Campus Map and Virtual Tour | Caraga State University. (n.d.). Retrieved July 17, 2018, from Http://Www.Carsu.Edu.Ph/?Q=about-Csu/Campus-Map-and-Virtual-Tour - Google Search n.d.)

Profile of graduate students of CSU in Mathematical investigation and modeling (MIM).

Respondents' records and socio-demographic information used as pointers to measure the frequencies and percentages of distributions as the basis of analyzing the data, this can be seen in Table 1a. While, Tables from $1 \mathrm{~b}-1 \mathrm{~h}$, shows the distribution of respondents by all of the variables specified therein.

Table 1a. Profile of graduate students in CSU-MIM, concerning their records, Second Semester, 2017-2018

\begin{tabular}{|c|c|c|c|c|c|c|c|}
\hline Respondent & Age & Sex & $\begin{array}{c}\text { Marital } \\
\text { Status } \\
\end{array}$ & $\begin{array}{c}\text { Employment } \\
\text { Status } \\
\end{array}$ & $\begin{array}{c}\text { BS } \\
\text { Degree }\end{array}$ & Residential & $\begin{array}{c}\text { No. of } \\
\text { siblings }\end{array}$ \\
\hline 1 & 23 & Female & Married & No work & BS Math & $\begin{array}{l}\text { Macalang, Buenavista, Agusan } \\
\text { del Norte }\end{array}$ & 7 \\
\hline 2 & 42 & Female & Married & Permanent & BSE Math & Cabadbaran, Agusan Norte & 5 \\
\hline 3 & 28 & Female & Married & Permanent & $\begin{array}{l}\text { BSEd } \\
\text { Math }\end{array}$ & Masao, Butuan City & 8 \\
\hline 4 & 30 & Female & Single & Permanent & BSE Math & Butuan City & 7 \\
\hline 5 & 22 & Male & Single & No work & $\begin{array}{l}\text { BSEd } \\
\text { Math }\end{array}$ & Buenavista, Butuan City & 8 \\
\hline 6 & 36 & Female & Married & Permanent & $\begin{array}{l}\text { BSEd } \\
\text { Math }\end{array}$ & Magallanes, AND & 1 \\
\hline 7 & 23 & Female & Single & Contractual & $\begin{array}{l}\text { BSEd } \\
\text { Math }\end{array}$ & Baan KM.3, Butuan City & 7 \\
\hline 8 & 26 & Female & Single & Permanent & $\begin{array}{l}\text { BSEd } \\
\text { Math }\end{array}$ & $\begin{array}{l}\text { Doña Rosario, } \\
\text { Tubay, AND }\end{array}$ & 2 \\
\hline 9 & 23 & Male & Single & Permanent & $\begin{array}{l}\text { BSEd } \\
\text { Math }\end{array}$ & No address & 11 \\
\hline 10 & 22 & Female & Single & Permanent & $\begin{array}{l}\text { BSEd } \\
\text { Math }\end{array}$ & Brgy. 22, Gingoog City & 7 \\
\hline 11 & 23 & Male & Single & Permanent & $\begin{array}{l}\text { BSEd } \\
\text { Math }\end{array}$ & Lapinigan, San Francisco, AND & 8 \\
\hline 12 & 24 & Male & Single & Permanent & $\begin{array}{l}\text { BSEd } \\
\text { Math }\end{array}$ & Sta. Irene, ADS & 4 \\
\hline 13 & 22 & Female & Single & Permanent & $\begin{array}{l}\text { BSEd } \\
\text { Math }\end{array}$ & Nasipit, AND & 2 \\
\hline 14 & 21 & Female & Single & Probationary & $\begin{array}{l}\text { BSEd } \\
\text { Math }\end{array}$ & Butuan City & 4 \\
\hline 15 & 51 & Male & Married & Permanent & BSME & Bayugan City & 1 \\
\hline 16 & 32 & Male & Married & Permanent & $\begin{array}{l}\text { BSEd } \\
\text { Math }\end{array}$ & Butuan City & 1 \\
\hline 17 & 40 & Male & Married & Permanent & $\begin{array}{l}\text { BSEd } \\
\text { Math }\end{array}$ & Butuan City & 1 \\
\hline 18 & 26 & Female & Single & Permanent & $\begin{array}{l}\text { BSEd } \\
\text { Math }\end{array}$ & Bayugan City & 7 \\
\hline 19 & 42 & Female & Married & Permanent & $\begin{array}{l}\text { BSEd } \\
\text { Math }\end{array}$ & Bayugan City & 3 \\
\hline 20 & 32 & Male & Married & Permanent & BS Math & Sibagat, ADS & 2 \\
\hline
\end{tabular}

Table 1b. Sex

\begin{tabular}{|c|c|c|c|c|c|}
\hline & & Frequency & Percent & Valid Percent & Cumulative Percent \\
\hline \multirow[t]{3}{*}{ Valid } & Male & 8 & 40.0 & 40.0 & 40.0 \\
\hline & Female & 12 & 60.0 & 60.0 & 100.0 \\
\hline & Total & 20 & 100.0 & 100.0 & \\
\hline
\end{tabular}


Table 1c. Age

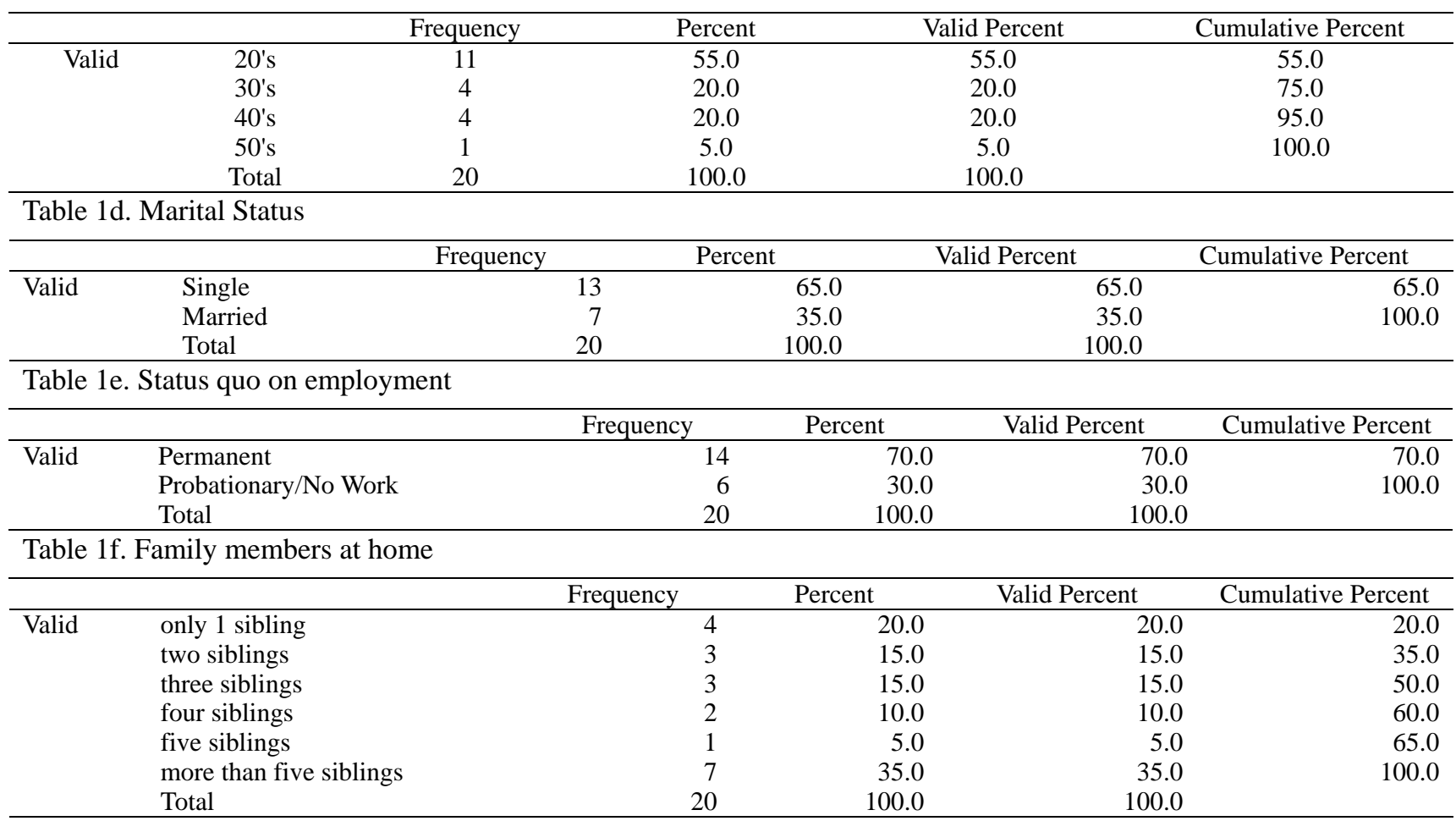

Table 1g. Baccalaureate degree completed

\begin{tabular}{llrrrr}
\hline & & Frequency & Percent & Valid Percent & Cumulative Percent \\
\hline Valid & BSEd Math & 13 & 65.0 & 65.0 & 65.0 \\
& BSE Math & 5 & 25.0 & 25.0 & 90.0 \\
& Others & 2 & 10.0 & 10.0 & 100.0 \\
& Total & 20 & 100.0 & 100.0 & \\
\hline
\end{tabular}

Table 1h. Home Address of respondent

\begin{tabular}{llllrrrr}
\hline & & & Frequency & Percent & Valid Percent & Cumulative Percent \\
\hline Valid & Within the parameter area of & 9 & 45.0 & 45.0 & 45.0 \\
& $\begin{array}{l}\text { Butuan City } \\
\text { Outside the parameter area of }\end{array}$ & 11 & 55.0 & 55.0 & 100.0 \\
$\begin{array}{l}\text { Butuan City } \\
\text { Total }\end{array}$ & & & 20 & 100.0 & 100.0 & \\
\hline
\end{tabular}

Table 1a and Tables from 1b-1h. Frequency counts and percentages of the graduate students in Mathematics investigation and modeling in CSU, that majority are female (12 or 60\%), and minority are male ( 8 or $40 \%$ ), their ages were from 20 to 50 years old of which majority of the age level full under the age of twenties (55\%) with frequency counts of 11 out of 20, while, the marital status mostly were single in a percentage of 65:35, acquired Mathematics Bachelor's degree in BSEd, BSE and other related courses in a ratio of 13:5:2, Majority has its tenure of appointment in a count of 16, while the rest is under contractual or probationary status, 7 of these respondents has more than "5 siblings", 1 respondent has "five siblings" 2 respondents have "4 siblings", 3 respondents have "3 siblings", 3 respondents has "2 siblings," and 4 respondents has "1 sibling", most of these respondents where geographically beyond the boundaries of Butuan City with percentile records of 60:40. 
Table 2.1. Learner's perspective on their teacher's instructional techniques with the scale specified from 1 to 5 . Wherein 1 , is equated to Strongly Disagree (SD); 2, is Disagree (D); 3, is Neutral (N); 4, is Agree (A); and 5, is Strongly Agree (SA) (20 respondents)

\begin{tabular}{|c|c|c|c|c|c|c|}
\hline Actual Observation and Experiences & 1 & 2 & 3 & 4 & 5 & $\begin{array}{l}\text { Mean } \\
\text { Value } \\
\text { (pdf) }\end{array}$ \\
\hline $\begin{array}{l}\text { 1. Proportion of learners who believed } \\
\text { that their professor is great, who inspired } \\
\text { and motivated his learners. }\end{array}$ & 0 & 0 & $\begin{array}{c}5 \\
(0.75)\end{array}$ & $\begin{array}{c}11 \\
(2.2)\end{array}$ & $\begin{array}{c}4 \\
(1)\end{array}$ & 3.95 \\
\hline $\begin{array}{l}\text { 2. Proportion of leaners who believed } \\
\text { that their professor has an exemplary } \\
\text { performance. }\end{array}$ & 0 & 0 & $\begin{array}{c}4 \\
(0.6)\end{array}$ & $\begin{array}{l}11 \\
(2.2)\end{array}$ & $\begin{array}{l}5 \\
(1.25)\end{array}$ & 4.05 \\
\hline $\begin{array}{l}\text { 3. Proportion of learners who believed } \\
\text { that their professor used the appropriate } \\
\text { instructional techniques. And made his } \\
\text { learners felt comfortable during classes. }\end{array}$ & 0 & $\begin{array}{c}1 \\
(0.1)\end{array}$ & $\begin{array}{c}3 \\
(0.45)\end{array}$ & $\begin{array}{c}11 \\
(2.2)\end{array}$ & $\begin{array}{c}5 \\
(1.25)\end{array}$ & 4.0 \\
\hline $\begin{array}{l}\text { 4. The proportion of learners who } \\
\text { believed that their professor is flexible } \\
\text { used computers and access internets in } \\
\text { giving advance instructions and } \\
\text { assignments. }\end{array}$ & 0 & $\begin{array}{c}1 \\
(0.1)\end{array}$ & $\begin{array}{c}3 \\
(0.45)\end{array}$ & $\begin{array}{c}11 \\
(2.2)\end{array}$ & $\begin{array}{l}5 \\
(1.25)\end{array}$ & 4.0 \\
\hline $\begin{array}{l}\text { 5. The proportion of learners who likes } \\
\text { the calmness of their Professor. }\end{array}$ & 0 & 0 & $\begin{array}{c}2 \\
(0.2) \\
\end{array}$ & $\begin{array}{c}8 \\
(1.60) \\
\end{array}$ & $\begin{array}{c}10 \\
(2.5)\end{array}$ & 4.30 \\
\hline $\begin{array}{l}\text { 6. The proportion of learners who } \\
\text { believed that their professor logical, uses } \\
\text { concrete examples as proof to his } \\
\text { lectures. }\end{array}$ & 0 & 0 & $\begin{array}{c}2 \\
(0.2)\end{array}$ & $\begin{array}{c}8 \\
(1.60)\end{array}$ & $\begin{array}{l}10 \\
(2.5)\end{array}$ & 4.30 \\
\hline $\begin{array}{l}\text { 7. The proportion of learners who } \\
\text { believed that their professor is dynamic, } \\
\text { he emphasizes the significant relations of } \\
\text { the historical studies in his teachings. }\end{array}$ & 0 & $\begin{array}{c}1 \\
(0.1)\end{array}$ & $\begin{array}{c}4 \\
(0.6)\end{array}$ & $\begin{array}{c}7 \\
(1.4)\end{array}$ & $\begin{array}{l}8 \\
(2)\end{array}$ & 4.10 \\
\hline $\begin{array}{l}8 . \text { The proportion of learners who } \\
\text { believed that their professor is } \\
\text { systematic, he knows how to transform } \\
\text { his learners in its desirable outcomes. }\end{array}$ & 0 & 0 & $\begin{array}{c}3 \\
(0.45)\end{array}$ & $\begin{array}{c}9 \\
(1.8)\end{array}$ & $\begin{array}{l}8 \\
(2)\end{array}$ & 4.25 \\
\hline $\begin{array}{l}\text { 9. The proportion of learners who } \\
\text { believed that their professor is } \\
\text { accommodating, he is fond of feed } \\
\text { backing. }\end{array}$ & 0 & 0 & $\begin{array}{c}2 \\
(0.2)\end{array}$ & $\begin{array}{c}8 \\
(1.60)\end{array}$ & $\begin{array}{c}10 \\
(2.5)\end{array}$ & 4.30 \\
\hline
\end{tabular}


Table 2.2. Data on Learners' perspective to their teacher's behavior in the Classroom with the criterion for mean values as follows: Very Low 1.0 - 1.80; Low 1.81 - 2.60; Average 2.61 - 3.40; High 3.41 - 4.20; and Very High 4.21 - 5.0 (20 Respondents)

\begin{tabular}{|c|c|c|c|c|c|c|c|}
\hline \multirow{2}{*}{ STATEMENTS } & \multicolumn{5}{|c|}{ Choices } & \multirow{2}{*}{ WM } & \multirow{2}{*}{ VD } \\
\hline & 1 & 2 & 3 & 4 & 5 & & \\
\hline $\begin{array}{l}\text { 1. My professor is great, he inspires and } \\
\text { motivates me on my studies. }\end{array}$ & 0 & 0 & 5 & 11 & 4 & 3.95 & High \\
\hline $\begin{array}{l}\text { 2. My professor has an exemplary } \\
\text { performance in teaching; he made me } \\
\text { understand the lesson. }\end{array}$ & 0 & 0 & 4 & 11 & 5 & 4.05 & High \\
\hline $\begin{array}{l}\text { 3. My professor uses appropriate } \\
\text { instructional techniques; he made me feel } \\
\text { comfortable during classes. }\end{array}$ & 0 & 1 & 3 & 11 & 5 & 4.0 & High \\
\hline $\begin{array}{l}\text { 4. My professor is flexible; he uses } \\
\text { internets and computer in giving advance } \\
\text { instructions and assignments. }\end{array}$ & 0 & 1 & 3 & 11 & 5 & 4.0 & Very High \\
\hline $\begin{array}{l}\text { 5. My professor is calm and relaxed, he is } \\
\text { pleasant to me even when I am late and } \\
\text { absent as well as I am honest and focused } \\
\text { on my studies. }\end{array}$ & 0 & 0 & 2 & 8 & 10 & 4.4 & Very High \\
\hline $\begin{array}{l}\text { 6. My professor is concrete and logical, he } \\
\text { gave examples and proofs to his lectures } \\
\text { and convened his learners to understand } \\
\text { the topics. }\end{array}$ & 0 & 0 & 2 & 8 & 10 & 4.4 & Very High \\
\hline $\begin{array}{l}\text { 7. My professor is dynamic; he } \\
\text { emphasizes the significant relations of the } \\
\text { historical studies in his teachings. }\end{array}$ & 0 & 1 & 4 & 7 & 8 & 4.1 & High \\
\hline $\begin{array}{l}\text { 8. My professor is systematic; he knows } \\
\text { how to transform me into the desired } \\
\text { outcomes based on the resembling system. }\end{array}$ & 0 & 0 & 3 & 9 & 8 & 4.25 & Very High \\
\hline $\begin{array}{l}\text { 9. My professor is accommodating; he is } \\
\text { fond of feedbacking. }\end{array}$ & 0 & 0 & 2 & 8 & 10 & 4.4 & Very High \\
\hline
\end{tabular}

VD, verbal description

Table 2.1-2.2, showcase overall results that teacher's greatness in motivation and teaching strategies has the lowest mean value of 3.95 and 4.4 is the highest mean. Teacher greatness was not the main factor that inspired his students to be more desirable, but it was his behavior in the classroom being flexible, calm, cool, concrete, logical, and systematic and accommodating during lectures at the school.

Table 3. Learners' feelings, on their teacher's methodology

\begin{tabular}{ccc}
\hline & $\mathrm{f}$ & \\
\hline I am comfortable in: & 9 & \\
\hline Teacher-focused & 45.0 & 60.0 \\
Dialogue oriented & 12 & \\
Student-focused & 15 & \\
\hline I prefer to study when I am: & 13 & 65.0 \\
Alone & 12 & 60.0 \\
With my teacher & 6 & 30.0 \\
With my teacher & 20 & \\
\hline Do you need a teacher's feedback & 0 & \\
\hline Yes & & \\
No & 100 \\
\hline I need a teacher's comments/feedback & 12 \\
\hline Right away & 8 & 60.0 \\
The next session & 60.0 \\
Anytime thru email & 30.0 \\
\hline
\end{tabular}

Based on frequency and percentage counts, the majority of the learners has described that their teacher utilized Student focused as means of instructional techniques in the classroom, indicated in Table 3. And it can be seen that most of the respondents preferred to study alone and to feel comfortable once their teacher used student-focused strategies in teaching. Although, students have complex ideas on feedbacking but rest assured all of them needs their teacher's feedback. 
Table 4. Significant factors, which affects the teacher's instructional techniques effectively

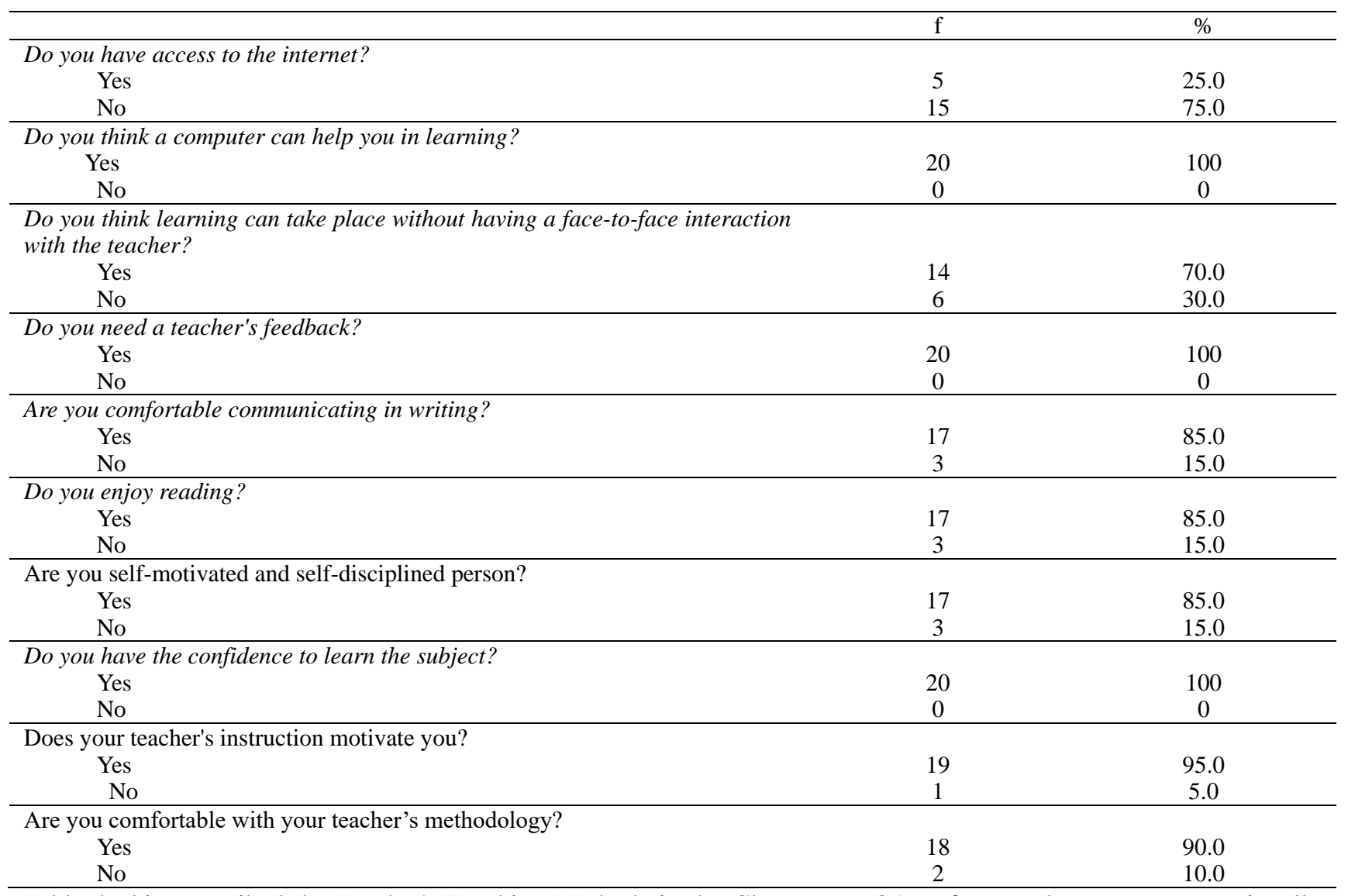

Table 4, this prescribed the Teacher's Teaching Methods in the Classroom. 85\% of respondents were proportionally motivated and self-disciplined, $100 \%$ with confidence to learn the subject, and 100\% liked their teacher's feedbacking. 6 out of 20 respondents thought to believed that learning could take place without having a face-to-face interaction with the teacher, 2 out of 20 respondents felt uncomfortable with their teacher's methodology, 3 are not comfortable communicating in writing, 3 has no reading habits, 2 accepted that they were not self-motivated, 2 confessed that they are not satisfied with their teacher's methodology, and 1 doesn't need the teacher's motivation.

\section{Conclusion and Recommendation}

Based on findings, the study interprets that Filipinos mathematicians' in this generation are majority woman, and responsive young professionals, endowed with virtues of being a loner, enthusiast, and well mannered.

The study has successfully measured the perspective views of CSU graduate students regarding their teacher's instructional techniques in Mathematical investigation and modeling and secured all of the answers of the specified questions therein.

First, most of the graduate students of CSU in Mathematical investigation and modeling for the first semester, school year, 2017-2018 are bachelors with a mainstream degree of BSED, bursting at the ages of the twenties, dominated by females, mainly with permanent tenure, frequently with siblings of 7 in a range of 1-15, and almost teachers in professions coming from nearby cities and towns.

Second, pragmatically students felt comfortable during the learning-process by way of students focus strategies, right after the sessions most of the students wanted to have their teacher's feedback. There was a more significant number of students who preferred to be alone when they took their studies than to be with their teacher or classmates.

Third, Students slightly preferred to study when they are alone than to be with their classmates, or when they are with their teacher, but then entirely they need their teacher's feedback and as soon as possible.

Fourth, this study tells that the teacher assumed the subject taught, simplified situations under intricacies such that most of the students have no internet access at home, though they believed that computer could help them in learning. Students felt that learning could take place without having a face-to-face interaction with their teacher, and they were comfortable communicating in writing and enjoyed reading. 
Fifth, by evidence, the factors that affect the teacher's instructional techniques to be more effective were because the teacher itself has desirable virtues, and students are self-motivated with self-disciplined, and with confidence to learn the subject.

Sixth, The study contemplated that $\mathrm{H}_{1}$ : Students personal and socio-demographic has no significance to their attitudes and habits in the Classroom; $\mathrm{H}_{2}$ : Teacher instructional techniques has its relevance to motivate, conveyed the learners and learned the topics; $\mathrm{H}_{3}$ : Teacher virtues has significance in transforming their students; $\mathrm{H}_{4}$ : Technology has the importance in communication, and $\mathrm{H}_{5}$ : There is no significant relationship between the teacher's instructional techniques across the learners' personal and the related socio-demographic records of the students.

Somehow the researcher declared that his experienced in CSU, has admitted to the theory of Stephen Kuo that "God has created Teachers to guides, to show the ways so we can decide how to do, what's the right instead of wrong. In wisdom and his grace, God created teachers to help us learn and to make our world a better, and a wiser place" (Kuo, Stephen 2010). Therefore, this study recommends: (1) to recognized those teachers with great intentions and adopt his virtues and instructional techniques in teaching; (2) to understand the weaknesses of students and provide for his welfare; (3) every teacher in all level from primary, secondary and to higher educations should bear in mind that "the desired teacher is a leader, that shall always keep the best means for his students." and (4) keeping this kind of teachers and his strategies in the learning process would help the world sustain the purpose of teaching.

\section{Acknowledgments}

First and foremost this study could not be realized without the benevolent and apostolates desires of those few. Surigao State College of Technology (SSCT), the researcher sending higher education institution (SHEI) who set forth him in lieu to his professional growth and underwent to his graduate studies in CSU, his delivering higher education institution (DHEI) and the Commission of Higher Education (CHED) who posturized as granting institution of the Kto12 scholarship transition program, wherein the researcher is one of the beneficial as grantee. And this is also to acknowledge the previous researchers who profoundly indulges there time and efforts just to contribute their simple means of understanding towards specific phenomenon, discovery, policy \& principle, experience, etc., either to share, educate, or even impress the readers about their conclusive thoughts and ideas, more particular to the following referred articles, below:

\section{References}

Acosta, I. C., \& Acosta, A. S. (2016). Teachers' Perceptions on Senior High School Readiness of Higher Education Institutions in the Philippines. Universal Journal of Educational Research, 4(10), 2435-2450. https://doi.org/10.13189/ujer.2016.041024.

de Guzman, A. B. (2003). The educational reforms in the Philippine basic and higher education sectors. Asia Pacific Education Review, 4(1), 39-50. https://doi.org/10.1007/BF03025551

Kuo, S. (2010). Successful and Satisfied for Teachers, pages 6-7.

Oginni, O. I., \& Owolabi, O. T. (2012). Integration of Programmed Instruction into Mathematics and Science Teaching: A Panacea to Students Dwindling Interest in Mathematics and Science in Nigerian Schools. European Journal of Educational Research, 11. https://doi.org/10.12973/eu-jer.1.3.199

Prado, N. L., Penaso, A. M., Cimene, F. T., Aves, L. S., \& Simbulas, S. G. (2011). Methods of Research, page 68, page 147 \& 184. - Google Search. (n.d.). Retrieved July 26, 2018.

Prieto, N. G., Naval, V. C., \& Carey, T. G. (2017). Practical Research. Campus Map and Virtual Tour | Caraga State University. (n.d.). Retrieved July 17, 2018, from

http://www.carsu.edu.ph/?q=about-csu/campus-map-and-virtual-tour - Google Search. (n.d.). Retrieved July 26, 2018.

Remesh, A. (2013). Microteaching, an efficient technique for learning effective teaching. (n.d.). Retrieved July 17, 2018, from https://www.ncbi.nlm.nih.gov/pmc/articles/PMC3724377/

Urhahne, D. (2015). Teacher behavior as a mediator of the relationship between teacher judgment and students' motivation and emotion. Teaching and Teacher Education, 45, January 2015, Pages 73-82. https://doi.org/10.1016/j.tate.2014.09.006

\section{Copyrights}

Copyright for this article is retained by the author(s), with first publication rights granted to the journal.

This is an open-access article distributed under the terms and conditions of the Creative Commons Attribution license which permits unrestricted use, distribution, and reproduction in any medium, provided the original work is properly cited. 